\title{
Nickel and Cobalt Complexes of Non-protein L-Norvaline and Antioxidant Ferulic Acid: Potentiometric and Spectrophotometric Studies
}

\author{
Artik Elisa Angkawijaya - Ahmed E. Fazary • \\ Erzalina Hernowo • Suryadi Ismadji • Yi-Hsu Ju
}

Received: 27 May 2011 / Accepted: 13 October 2011 / Published online: 13 July 2012

(C) Springer Science+Business Media, LLC 2012

\begin{abstract}
Binary and mixed-ligand complexes of $\mathrm{Ni}^{2+}$ and $\mathrm{Co}^{2+}$ involving L-norvaline (Nva) and ferulic acid (FA) have been investigated in aqueous solutions by $\mathrm{pH}$ potentiometry and UV-visible spectrophotometric techniques, at $298.15 \mathrm{~K}$ and fixed ionic strength $\left(0.15 \mathrm{~mol} \cdot \mathrm{dm}^{-3}, \mathrm{NaNO}_{3}\right)$. The overall stability constants of the $\mathrm{Ni}^{2+}$ and $\mathrm{Co}^{2+}$ complexes with the ligands studied were obtained by the HYPERQUAD2008 program from the $\mathrm{pH}-$ potentiometric data. As a result of the numerical treatment, a model composed of seven species $\mathrm{NiNva}^{+}, \mathrm{NiNva}_{2}, \mathrm{NiNvaH}_{-1}, \mathrm{NiNva}_{-2}^{-}, \mathrm{NiFA} \mathrm{NiFAH}_{-1}^{-}$and $\mathrm{NiNvaFA}^{-}$was obtained for the $\mathrm{Ni}^{2+}+\mathrm{Nva}+\mathrm{FA}$ system, whereas for the $\mathrm{Co}^{2+}+\mathrm{Nva}+\mathrm{FA}$ system the complexes $\mathrm{CoNva}^{+}, \mathrm{CoNva}_{2}, \mathrm{CoNvaH}_{-1}, \mathrm{CoNvaH}_{-2}^{-}, \mathrm{CoFA} \mathrm{CoFAH}_{-1}^{-}$, and $\mathrm{CoNvaFA}^{-}$ were obtained. The complex species distributions in certain $\mathrm{pH}$ ranges were calculated by the HySS2009 simulation program. Spectroscopic UV-visible measurements were carried out to give qualitative information about the complexes formed in these solutions.
\end{abstract}

Keywords L-norvaline · Ferulic acid · Complexation · Equilibria

\footnotetext{
A.E. Angkawijaya · E. Hernowo · Y.-H. Ju (凶)

Department of Chemical Engineering, National Taiwan University of Science and Technology,

43 Keelung Road, Section 4, Taipei 106-07, Taiwan

e-mail: yhju@mail.ntust.edu.tw
}

A.E. Fazary

Chemistry Department, Faculty of Science, King Khalid University, Abha 9004, Saudi Arabia e-mail: aefazary@gmail.com

A.E. Fazary

Applied Research Sector, Egyptian Organization for Biological Products and Vaccines, Cairo, Egypt

S. Ismadji

Department of Chemical Engineering, Widya Mandala Surabaya Catholic University, Kalijudan 37,

Surabaya 60114, Indonesia

e-mail: suryadiismadji@yahoo.com 


\section{Introduction}

Nickel and cobalt are essential trace elements for the human body. Nickel is a cofactor of many enzymes, whereas cobalt is a primary component of vitamin B12. This vitamin plays an important role in growth development, metabolic processes, and nervous system and brain functions. It is used in the treatment for anemia, since it helps red blood cell production [1-7]. However, exposure of the human body to these elements in excessive amounts causes various negative effects on health. The most commonly reported adverse health effect of excess nickel exposure is contact dermatitis, which is the result of an allergic reaction to nickel. Moreover, nickel is a respiratory toxicant that can cause acute lung inflammation, chronic bronchitis, emphysema, pulmonary fibrosis, and can induce lung or nasal cancer $[8,9]$. Similar to nickel, cobalt exposure mainly affects the human respiratory system. Exposure of these elements also affects the gastrointestinal tract, kidney, cardiac, immunological and neurological systems [8-12].

Metal-ligand complexes have been used as metal-poisoning antidotes. Such an antidote circulates in the blood stream and reduces metal concentrations in the human body [13-15]. A number of ligands have been used as antidotes to combat metal poisoning, such as EDTA, amino acids, hydroxamic acids and phenolic acids. In a recent study [16] we investigated the stability constants of a number of complexes formed by L-norvaline (Nva) and trans-ferulic acid (FA) with transition metal ions $\left(\mathrm{Fe}^{3+}, \mathrm{Cr}^{3+}\right.$ and $\left.\mathrm{Cu}^{2+}\right)$. Since $\mathrm{Nva}$ and FA show strong chelating ability [17-20], it is natural to extend the earlier work to complexation of these two ligands with $\mathrm{Ni}^{2+}$ and $\mathrm{Co}^{2+}$. The objective of this study is to quantify the metal chelating activity of $\mathrm{Nva}$ and $\mathrm{FA}$ with $\mathrm{Ni}^{2+}$ and $\mathrm{Co}^{2+}$. Besides, these compounds also show many beneficial effects for the human body, such as antioxidant, anti-inflammatory, and anticancer effects and have a therapeutic effect on tumors [21-32]. Monitoring of complex formation of ligands and metal ions was accomplished with a potentiometric technique with a glass electrode, and the experimental data were analyzed using HYPERQUAD2008 [33]. Graphic representations of the complex species formed in certain $\mathrm{pH}$ ranges, as distribution diagrams, were produced with the HySS2009 [34] modeling program. Also, UV-vis spectroscopic analyses were used to verify the formation of metal ligand complexes.

\section{Experimental}

\subsection{Material and Solution}

All chemicals were analytical grade and were used without further purification. L-Norvaline (Nva, $\mathrm{C}_{5} \mathrm{H}_{11} \mathrm{NO}_{2}, 99 \%$ ) was purchased from Merck (Germany) and trans-ferulic acid (FA, $99 \%$ ) was obtained from Aldrich (Germany). Carbonate-free sodium hydroxide solution was purchased from Acros Organics (USA) and the solution was standardized potentiometrically with potassium hydrogen phthalate (Sigma-Aldrich, USA).

Nickel chloride hexahydrate $\left(\mathrm{NiCl}_{2} \cdot 6 \mathrm{H}_{2} \mathrm{O}\right)$, cobalt nitrate hexahydrate $\left(\mathrm{Co}\left(\mathrm{NO}_{3}\right)_{2}\right.$. $\left.6 \mathrm{H}_{2} \mathrm{O}\right)$, and sodium nitrate $\left(\mathrm{NaNO}_{3}\right)$ were purchased from Acros Organics (USA). The nitric acid (Pancreac, Spain) solution used to acidify other solutions was prepared and standardized before use. All solutions in the experiments were prepared freshly before use, using ultra pure water obtained from a NANO Pure Ultrapure water system (distilled and deionized giving a resistance of $18.3 \mathrm{M} \Omega \cdot \mathrm{cm}^{-1}$ ). 


\section{$2.2 \mathrm{pH}-$ Potentiometric Measurements}

\subsubsection{Procedure}

The $\mathrm{pH}$-potentiometric titrations were performed using a Metrohm 702 SM Titroprocessor with a 664 Dosimat, a 728 magnetic stirrer, coupled with a Dosino burette model 683 . The electrode response can be read to the third decimal place in terms of $\mathrm{pH}$ units with a precision of \pm 0.001 . The titroprocessor was coupled to a personal computer and the titration software TINET version 2.4 was used to control the titration and data acquisition. The $\mathrm{pH}$ meter was calibrated with standard buffer solutions $(\mathrm{pH}=4.00,7.00$ and 9.21) before and after each series of $\mathrm{pH}$ measurements.

For the determination of binary and mixed ligand complexes, the following solutions were prepared (total volume $50 \mathrm{~cm}^{3}$ ) and titrated potentiometrically against a standard carbonate-free $\mathrm{NaOH}\left(0.1 \mathrm{~mol} \cdot \mathrm{dm}^{-3}\right)$ solution:

(a) $0.003 \mathrm{~mol} \cdot \mathrm{dm}^{-3} \mathrm{HNO}_{3}+0.15 \mathrm{~mol} \cdot \mathrm{dm}^{-3} \mathrm{NaNO}_{3}$;

(b) solution (a) + Nva or FA;

(c) solution (a) + Nva or FA + metal ions $\left(\mathrm{Ni}^{2+}\right.$ or $\left.\mathrm{Co}^{2+}\right)$;

(d) solution (a) $+\mathrm{Nva}+\mathrm{FA}+$ metal ions $\left(\mathrm{Ni}^{2+}\right.$ or $\left.\mathrm{Co}^{2+}\right)$.

The protonation constants of Nva and FA were determined potentiometrically by titrating mixture (b). The stability constants of the binary complexes of $\mathrm{Ni}^{2+}$ or $\mathrm{Co}^{2+}$ with $\mathrm{Nva}$ and FA were determined by titrating mixture (c). The stability constants of the mixed-ligand complexes of $\mathrm{Nva}$ and $\mathrm{FA}$ with $\mathrm{Ni}^{2+}$ or $\mathrm{Co}^{2+}$ were calculated using potentiometric data obtained from mixture (d).

The ionic strength of the solutions was maintained at $0.15 \mathrm{~mol} \cdot \mathrm{dm}^{-3}$ by using the desired concentration of $\mathrm{NaNO}_{3}$ as the supporting electrolyte. The ligand concentrations in the titrated samples were varied from 0.0004 to $0.0012 \mathrm{~mol} \cdot \mathrm{dm}^{-3}$. For binary complexes, potentiometric titrations were carried out using four molar ratios of metal-to-ligand (1:1, $1: 2,1: 2.5$ and $1: 3$ ) to fulfill the maximum possible coordination number of the metal ion, and the ratio 1:1:1 was used for the ternary systems. Each solution was thermostatted at $25 \pm 0.1{ }^{\circ} \mathrm{C}$, and the solution was left to stand for several minutes before titration. A magnetic stirrer was used during all titrations. Each titration was repeated at least three times under carefully controlled experimental conditions.

\subsubsection{Data Analysis}

The determinations of the protonation constants of ligands and the overall stability constants of their metal complexes from the $\mathrm{pH}$ titration data were performed using the HYPERQUAD2008 program [33]. Corresponding to previous work [16], the ionization constant of water $\left(\mathrm{p} K_{\mathrm{w}}\right)$ in $0.15 \mathrm{~mol} \cdot \mathrm{dm}^{-3} \mathrm{NaNO}_{3}$ is 13.77 at $298 \mathrm{~K}$. The stoichiometries and stability constants of the complexes formed were determined by trying various possible composition models (using titration results obtained before precipitation or opalescence was observed in the solution). The selected model was the one that gave the best statistical fit and seemed chemically sensible and consistent with the titration data, without giving any systematic drifts in the magnitudes of the various residuals.

\subsection{Spectrophotometric Measurements}

The absorption spectra were obtained using an UV-vis spectrophotometer (Varian Cary 50, USA). Spectra of solutions containing $\mathrm{Ni}^{2+}+\mathrm{FA}, \mathrm{Co}^{2+}+\mathrm{FA}, \mathrm{Ni}^{2+}+\mathrm{Nva}+\mathrm{FA}$ and 
$\mathrm{Co}^{2+}+\mathrm{Nva}+\mathrm{FA}$ were taken separately between $\mathrm{pH}=4.5$ and 11 over the wavelength interval of 200 to $450 \mathrm{~nm}$. The solutions were prepared with the same metal-to-ligand molar ratios as used in the $\mathrm{pH}$-potentiometric titrations.

\section{Results and Discussion}

\subsection{Potentiometric Results}

In our recent study [16], we reported the protonation constants of Nva and FA. Both of these ligands have two protonation sites. For Nva, associations of the protons occur at the amino group $\left(-\mathrm{NH}_{2}\right)$ and the carboxylic acid group $\left(-\mathrm{COO}^{-}\right)$, with overall proton association constant $\left(\log _{10} \beta\right)$ values of 9.29 and 11.90 , respectively. In contrast, the overall proton association constants for ferulic acid are 8.77 and 13.23, and protonation occurs at the para phenolic hydroxyl $\left(-\mathrm{O}^{-}\right)$and at the carboxylate group, respectively. These protonation constants values were obtained using the HYPERQUAD2008 program, and were used as input data for the evaluation of the overall stability constants of metal complexes using the same program. These values are in good agreement with those reported in literatures $[17,18,35,36]$ and the small differences are caused by differences in experimental conditions or calculation procedures used.

From the (typical) titration curves shown in Fig. 1, it can be seen that at a fixed titrant volume there is a shift in $\mathrm{pH}$ from that for the ligand alone to lower $\mathrm{pHs}$ for ligand-metal ion complexes. These shifts indicate that complexes formed in the binary and ternary systems.

Fig. 1 Potentiometric titration curves of (a) the $\mathrm{Ni}^{2+}+\mathrm{Nva}+\mathrm{FA}$ system and (b) the $\mathrm{Co}^{2+}+\mathrm{Nva}+\mathrm{FA}$ system, both at $T=298.15 \mathrm{~K}$ and $I=0.15 \mathrm{~mol} \cdot \mathrm{dm}^{-3} \mathrm{NaNO}_{3}$; $\left[\mathrm{M}^{2+}\right]=0.0004 \mathrm{~mol} \cdot \mathrm{dm}^{-3}$ and [ligands] $=0.001 \mathrm{~mol} \cdot \mathrm{dm}^{-3}$ for the binary systems; $\left[\mathrm{M}^{2+}\right]$ and [ligands] $=0.001 \mathrm{~mol} \cdot \mathrm{dm}^{-3}$ for the ternary system
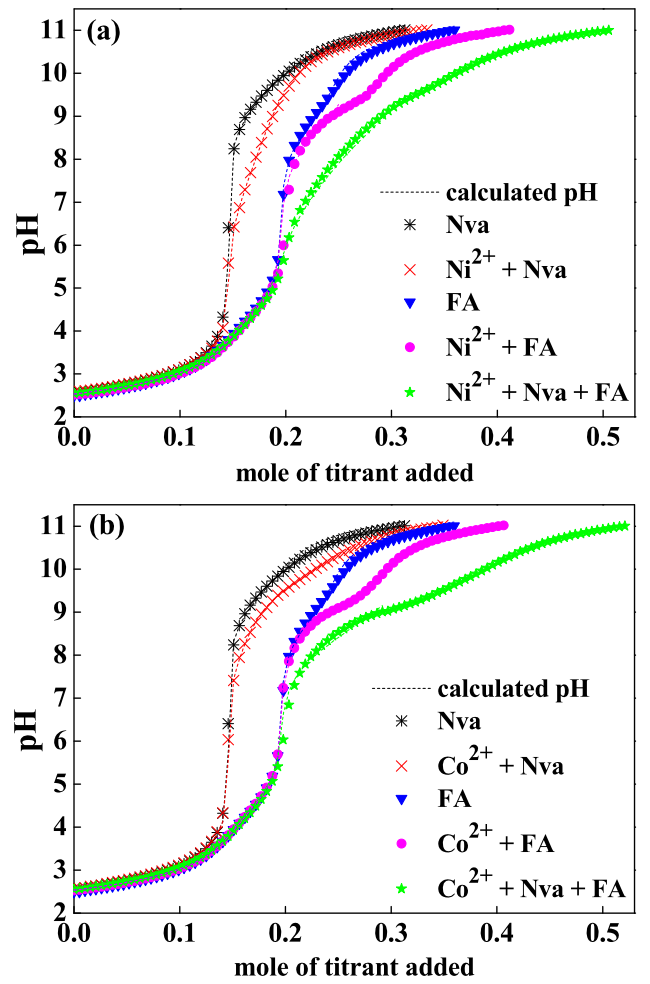
Table 1 Logarithms of the overall stability constants $\left(\log _{10} \beta_{p q r s}\right)^{\mathrm{a}}$ of binary and ternary complexes of $\mathrm{Ni}^{2+}$ with L-norvaline (Nva) and ferulic acid (FA) in aqueous solution at $298.15 \mathrm{~K}$ and $I=0.15 \mathrm{~mol} \cdot \mathrm{dm}^{-3}$ $\mathrm{NaNO}_{3}$

\begin{tabular}{|c|c|c|c|c|c|c|}
\hline Complex & $p$ & $q$ & $r$ & $s$ & $\log _{10} \beta_{\text {pqrs }}$ & S.D. \\
\hline $\mathrm{NiNva}^{+}$ & 1 & 1 & 0 & 0 & $5.49(5.42)[18]$ & 0.0102 \\
\hline $\mathrm{NiNva}_{2}$ & 1 & 2 & 0 & 0 & $9.73(9.87)$ & 0.0157 \\
\hline $\mathrm{NiNvaH}_{-1}$ & 1 & 1 & 0 & -1 & -3.54 & 0.0222 \\
\hline $\mathrm{NiNvaH}_{-2}^{-}$ & 1 & 1 & 0 & -2 & -14.74 & 0.0652 \\
\hline $\mathrm{NiFA}$ & 1 & 0 & 1 & 0 & 3.70 & 0.0893 \\
\hline $\mathrm{NaFAH}_{-1}^{-}$ & 1 & 0 & 1 & -1 & -5.37 & 0.0626 \\
\hline $\mathrm{NiNvaFA}^{-}$ & 1 & 1 & 1 & 0 & 8.83 & 0.0740 \\
\hline$\Delta \log _{10} K$ & & & & & -0.35 & \\
\hline
\end{tabular}

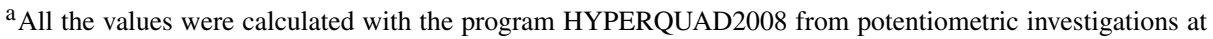
$298 \mathrm{~K}$ and $I=0.15 \mathrm{~mol} \cdot \mathrm{dm}^{-3} \mathrm{NaNO}_{3}$. The symbols $p, q, r$, and $s$ are used in the programs to indicate the stoichiometric coefficients associated with the possible equilibria in solutions

Table 2 Logarithms of the overall stability constants $\left(\log _{10} \beta_{\text {pqrs }}\right)^{\mathrm{a}}$ of binary and ternary complexes of $\mathrm{Co}^{2+}$ with L-norvaline (Nva) and ferulic acid (FA) in aqueous solution at $298.15 \mathrm{~K}$ and $I=0.15 \mathrm{~mol} \cdot \mathrm{dm}^{-3}$ $\mathrm{NaNO}_{3}$

\begin{tabular}{llllccr}
\hline Complex & $p$ & $q$ & $r$ & $s$ & $\log _{10} \beta_{\text {pqrs }}$ & S.D. \\
\hline CoNva $^{+}$ & 1 & 1 & 0 & 0 & $4.29(4.29)[18]$ & 0.0100 \\
CoNva $_{2}$ & 1 & 2 & 0 & 0 & $7.26(7.81)$ & 0.0572 \\
CoNvaH $_{-1}$ & 1 & 1 & 0 & -1 & -5.72 & 0.0554 \\
CoNvaH $_{-2}^{-}$ & 1 & 1 & 0 & -2 & -15.06 & 0.0095 \\
CoFA $_{\text {CoFAH }}^{-}$ & 1 & 0 & 1 & 0 & 3.06 & 0.0553 \\
CoNvaFA $^{-}$ & 1 & 0 & 1 & -1 & -5.88 & 0.0745 \\
$\Delta \log _{10} K$ & 1 & 1 & 1 & 0 & 7.71 & 0.0775 \\
\hline
\end{tabular}

${ }^{\text {a }}$ All the values were calculated with the program HYPERQUAD2008 from potentiometric investigations at $298 \mathrm{~K}$ and $I=0.15 \mathrm{~mol} \cdot \mathrm{dm}^{-3} \mathrm{NaNO}_{3}$. The symbols $p, q, r$, and $s$ are used in the programs to indicate the stoichiometric coefficients associated with the possible equilibria in solutions

Stability constant determinations for the complexes formed were accomplished by fitting the experimental data corresponding to the titration curves of $\mathrm{Ni}^{2+}$ and $\mathrm{Co}^{2+}$ with $\mathrm{Nva}$ and FA (using HYPERQUAD2008 program). The complexation reactions between metal ion $\left(\mathrm{M}^{2+}\right)$, Nva and FA can be described by the general equilibrium:

$$
\begin{aligned}
& { }_{p} \mathrm{M}+{ }_{q} \mathrm{Nva}+{ }_{r} \mathrm{FA}+{ }_{s} \mathrm{H} \rightleftharpoons \mathrm{M}_{p} \mathrm{Nva}_{q} \mathrm{FA}_{r} \mathrm{H}_{s} \\
& \beta_{\text {pqrs }}=\frac{\left[\mathrm{M}_{p} \mathrm{Nva}_{q} \mathrm{FA}_{r} \mathrm{H}_{s}\right]}{[\mathrm{M}]^{p}[\mathrm{Nva}]^{q}[\mathrm{FA}]^{r}[\mathrm{H}]^{s}}
\end{aligned}
$$

where $p, q, r$ and $s$ are the stoichiometric coefficients associated with the complexes formed from the metal ion, Nva, FA and proton, respectively.

The evaluated stability constants $\left(\log _{10} \beta_{\text {pqrs }}\right)$ for Nva and FA are presented in Tables 1 and 2 . The stability constant values for the Nva system with both $\mathrm{Ni}^{2+}$ and $\mathrm{Co}^{2+}$ are quite 
similar to those of the corresponding complexes with the $\alpha$-amino acid glycine; these results are reasonable since both systems have similar chelating sites $\left(-\mathrm{NH}_{2}\right.$ and $\left.-\mathrm{COO}^{-}\right)$. The $\log _{10} \beta$ values of the $\mathrm{M}^{2+}+$ glycine [37] system are 5.80 for $\mathrm{Ni}^{2+}$ and 4.66 for the $\mathrm{Co}^{2+}$ system, while for the $\mathrm{M}^{2+}+$ Nva system the overall stability constant values are 5.49 for $\mathrm{Ni}^{2+}$ and 4.29 for $\mathrm{Co}^{2+}$, respectively. These results suggest that the metal ions binding to the Nva ligand occur in a glycine-like structure.

For binary system with ferulic acid as ligand, it is suggested that FA acts as bidentate ligand for both $\mathrm{Ni}^{2+}$ and $\mathrm{Co}^{2+}$ since the obtained $\log _{10} \beta_{\mathrm{ML}}$ values for the $\mathrm{M}^{2+}+\mathrm{FA}$ complex are greater than the $\log _{10} \beta$ values of the individual chelating sites $\left(-\mathrm{COO}^{-}\right.$and $\left.-\mathrm{O}^{-}\right)$. The $\log _{10} \beta$ value of a $\mathrm{Ni}^{2+}$ system is 0.67 at a carboxyl site, while in a $\mathrm{Co}^{2+}$ system the $\log _{10} \beta$ value is 0.56 [38]. Unfortunately, $\log _{10} \beta$ values for $\mathrm{Ni}^{2+}$ and $\mathrm{Co}^{2+}$ systems could not be found in the literature at the hydroxyl site. However, these values are expected to be slightly higher than those at the corresponding carboxyl site.

The stability constant of a metal-ligand complex in a ternary system is related to those of the corresponding binary systems by $\Delta \log _{10} K$, which compares the stability of the ternary system to the binary systems, by the following relation:

$$
\Delta \log _{10} K=\log _{10} \beta_{\mathrm{MNvaFA}}^{\mathrm{MNva}}-\log _{10} \beta_{\mathrm{MNva}}^{\mathrm{M}}-\log _{10} \beta_{\mathrm{MFA}}^{\mathrm{M}}
$$

A positive value of $\Delta \log _{10} K$ indicates that the ternary complex is more stable than the binary complexes, while the opposite is true if $\Delta \log _{10} K$ is negative [39]. From the calculated $\Delta \log _{10} K$ values of the $\mathrm{Ni}^{2+}$ system, it can be seen that the ternary system is less stable, because there is a steric effect when FA binds to the metal-Nva complex. In contrast, for $\mathrm{Co}^{2+}$ the ternary system is more stable since $\mathrm{Co}^{2+}$ forms less stable complexes in the binary systems, so it has less steric hindrance to the secondary ligand binding with the metal-Nva complex.

From the trend of stability constant values, it can be concluded that the binary $\mathrm{Ni}^{2+}$ complexes are more stable than those of the $\mathrm{Co}^{2+}$ binary systems. This trend follows the Irving-Williams series of stability [40]. By comparing the ligand chelating abilities, it can be seen that Nva complexes more strongly with metal ions than FA. This phenomenon happens as a result of the ligand structure (Fig. 2). Since FA produces bulkier a chelate ring when complexing with a metal ion, the complex formed tends to be less stable [41-43].

HySS provides an integrated environment for setting up a calculation, performing it and creating speciation diagrams, etc. There are no limits imposed on the numbers of reagents, complexes or partially soluble products that may be present. Three types of calculation can be performed: (i) simulation of a titration curve, (ii) calculation of species' concentrations for a range of conditions, and (iii) speciation for a single set of conditions (single data

(a)

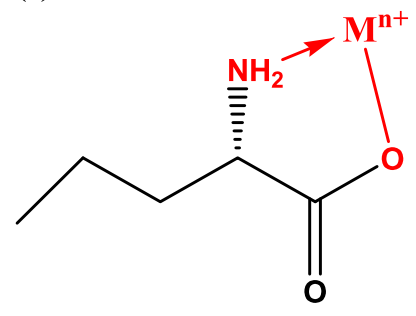

(b)

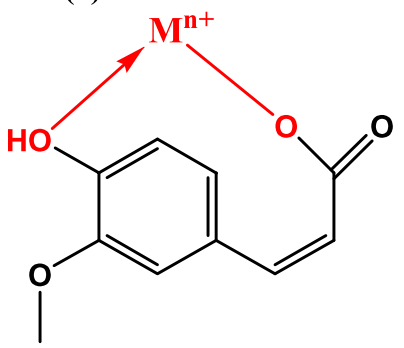

Fig. 2 Coordination models of (a) L-norvaline and (b) trans-ferulic acid 

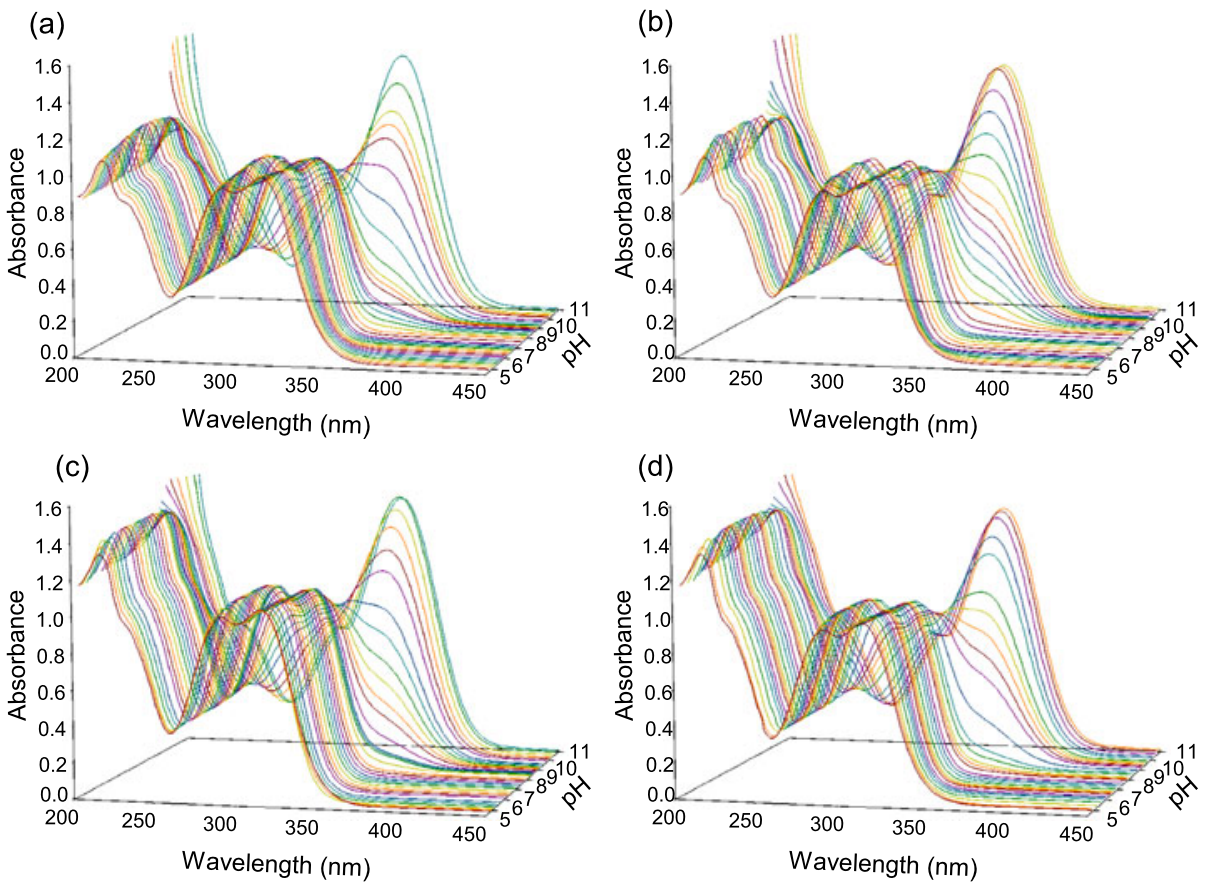

Fig. 3 UV-vis spectra of (a) $\mathrm{Ni}^{2+}+\mathrm{FA},(\mathbf{b}) \mathrm{Ni}^{2+}+\mathrm{Nva}+\mathrm{FA},(\mathbf{c}) \mathrm{Co}^{2+}+\mathrm{FA}$, and (d) $\mathrm{Co}^{2+}+\mathrm{FA}+\mathrm{Nva}$ systems at $T=298.15 \mathrm{~K} ;\left[\mathrm{M}^{2+}\right]=0.0004 \mathrm{~mol} \cdot \mathrm{dm}^{-3}$ and $[$ ligands $]=0.001 \mathrm{~mol} \cdot \mathrm{dm}^{-3}$ for binary systems; $\left[\mathrm{M}^{2+}\right]$ and [ligands $]=0.001 \mathrm{~mol} \cdot \mathrm{dm}^{-3}$ for ternary systems

points) [34]. From the species distribution diagrams, a simulation of the amounts of complex formed in binary and ternary system at a certain $\mathrm{pH}$ value can be performed. In the $\mathrm{Ni}^{2+}+$ Nva system, the NiNva complex starts to form at $\mathrm{pH}=5$ and the maximum concentration (approximately $33 \%$ ) occurs at $\mathrm{pH}=7.9$, which is then followed by formation of the $\mathrm{NiNva}_{2}$ complex (ca. $28 \%$ ) at $\mathrm{pH}=9.2$. For the $\mathrm{Co}^{2+}+$ Nva system, the CoNva complex starts to form at $\mathrm{pH}=6$ and the maximum concentration occurs at $\mathrm{pH}=9$ (ca. $30 \%$ ).

For the binary complexes of a metal ion with FA, the NiFA complex starts to form at $\mathrm{pH}=6$ and reaches a maximum concentration (ca. $20 \%$ ) at $\mathrm{pH}=8.7$, while the CoFA complex concentration at $\mathrm{pH}=8.9$ is approximately $10 \%$. The mixed ligand species distribution diagrams show that the percent formation of ternary species overlaps with the binary complex of Nva and this result is consistent with the $\Delta \log _{10} K$ values.

\subsection{Spectrophotometric Results}

The UV-vis spectra of $\mathrm{Ni}^{2+} / \mathrm{Co}^{2+}+\mathrm{Nva}+\mathrm{FA}$ at $\mathrm{pH}=4.5-11$ are shown in Fig. 3. Three absorbance peaks are found at $215 \mathrm{~nm}, 289 \mathrm{~nm}$ and $313 \mathrm{~nm}(\mathrm{pH}=4.5)$. In the $\mathrm{Ni}^{2+}+\mathrm{FA}$ system, as the $\mathrm{pH}$ is increased to 7.2 , the $289 \mathrm{~nm}$ and 313 peaks are shifted hypsochromically to $286 \mathrm{~nm}$ and $310 \mathrm{~nm}$, respectively, while the peak at $215 \mathrm{~nm}$ shifts hyperchromically to greater absorbance value. The peaks start to shift bathochromically with increasing $\mathrm{pH}$ and, at about $\mathrm{pH}=9$, the peak at $286 \mathrm{~nm}$ slowly subsides while the peak at $313 \mathrm{~nm}$ broadens and shifts bathochromically to $345 \mathrm{~nm}$. The shifting of $\mathrm{Ni}^{2+}+\mathrm{FA}$ peaks around $\mathrm{pH}=7.2 \mathrm{might}$ be caused by the formation of the NiFA complex in solution. 
For the $\mathrm{Ni}^{2+}+\mathrm{Nva}+\mathrm{FA}$ ternary system, the hypsochromic shift occurs at $\mathrm{pH}=6$ (286 $\mathrm{nm}$ and $309 \mathrm{~nm}$ ), then the peaks start to shift bathochromically, and at about $\mathrm{pH}=$ 9.2 the peak at $286 \mathrm{~nm}$ slowly subsids while the peak at $313 \mathrm{~nm}$ broadens and shifts bathochromically to $345 \mathrm{~nm}$. Similar results were obtained for the $\mathrm{Co}^{2+}$ system. Initially the peak shifts hyperchromically, then at about $\mathrm{pH}=8-9$ the $313 \mathrm{~nm}$ peak broadens and shifts to $345 \mathrm{~nm}$. This shifting in the spectra indicates that the ligand is bound to the metal and forms binary and mixed ligand complexes.

Acknowledgements This work was supported by the National Science Council of Taiwan through projects NSC 98-2221-E-011-046-MY3 and 97-ET-7-011-001-ET. The authors thank Dr. Mohamed Taha for valuable discussion regarding this manuscript.

\section{References}

1. Zoroddu, M.A., Peana, M., Kowalik-Jankowska, T., Kozlowski, H., Costa, M.: Nickel(II) binding to Cap43 protein fragments. J. Inorg. Biochem. 98, 931-939 (2004)

2. Kobayashi, M., Shimizu, S.: Cobalt proteins. Eur. J. Biochem. 261, 1-9 (1999)

3. Piero, S.D., Melchior, A., Polese, P., Portanova, R., Tolazzi, M.: Mixed nitrogen/oxygen ligand affinities for bipositive metal ions and dioxygen binding to cobalt(II) complexes. Dalton Trans. 1358-1365 (2004)

4. Rodionov, D.A., Hebbeln, P., Gelfand, M.S., Eitinger, T.: Comparative and functional genomic analysis of prokaryotic nickel and cobalt uptake transporters: evidence for a novel group of ATP-binding cassette transporters. J. Bacteriol. 188, 317-327 (2006)

5. Mulrooney, S.B., Hausinger, R.P.: Nickel uptake and utilization by microorganisms. FEMS Microbiol. Rev. 27, 239-261 (2003)

6. Bukhari, I.H., Hassan, M.N., Haleem, A., Bhatti, M.M.: Role of metals (cadmium and lead) in patients of hypertension and their relationship with ischemic heart disease. J. Agric. Biol. Sci. 1(2), 190-194 (2005)

7. Crichton, R.R.: Biological Inorganic Chemistry: An Introduction. Elsevier, Amsterdam (2008)

8. Duda-Chodak, A., Blaszczyk, U.: The impact of nickel on human health. J. Elem. 13, 685-696 (2008)

9. Toxicological Profile for Nickel. Agency for Toxic Substances and Disease Registry, U.S. Department of Health and Human Services, Atlanta, Georgia (2005)

10. Verougstraete, V., Mallants, A., Buchet, J.-P., Swennen, B., Lison, D.: Lung function changes in workers exposed to cobalt compounds. Am. J. Respir. Crit. Care Med. 170, 162-166 (2004)

11. Toxicological Profile for Cobalt. Agency for Toxic Substances and Disease Registry, Atlanta, Georgia (2004)

12. Mosconi, G., Bacis, M., Leghissa, P., Sala, C.: Occupational exposure to metallic cobalt. In: Cheremisinoff, P.N., Cheremisinoff, N.P. (eds.) Advances in Environmental Control Technology: Health and Toxicology. Elsevier, Amsterdam (1997)

13. Andersen, O.: Principles and recent developments in chelation treatment of metal intoxication. Chem. Rev. 99, 2683-2710 (1999)

14. Flora, S.J.S., Pachauri, V.: Chelation in metal intoxication. Int. J. Environ. Res. Public Health 7, 27452788 (2010)

15. Flora, S.J.S., Gubrelay, U., Kannan, G.M., Mathur, R.: Effects of zinc supplementation during chelating agent administration in cadmium intoxication in rats. J. Appl. Toxicol. 18, 357-362 (1998)

16. Angkawijaya, A.E., Fazary, A.E., Hernowo, E., Taha, M., Ju, Y.-H.: Iron(III), chromium(III), and copper(II) complexes of L-norvaline and ferulic acid. J. Chem. Eng. Data 56, 532-540 (2011)

17. Borges, F., Lima, J.L.F.C., Pinto, I., Reis, S., Siquet, C.: Application of a potentiometric system with data analysis computer programs to the quantification of metal-chelating activity of two natural antioxidants: caffeic acid and ferulic acid. Helv. Chim. Acta 86, 3081-3087 (2003)

18. Gergely, A., Sovago, I., Nagypal, I., Kiraly, R.: Equilibrium relations of alpha-aminoacid mixed complexes of transition metal ions. Inorg. Chim. Acta 6, 435-439 (1972)

19. Rao, A.K., Mohan, M.S.: Physicochemical studies on ternary complexes containing adenosine- $5^{\prime}-$ triphosphate, divalent metal ions and selected biomolecules. Proc. Indian Acad. Sci., Chem. Sci. 101, 1-7 (1989)

20. Tewari, B.B.: Studies on biologically important copper(II)/manganese(II)/uranyl (II)-norvaline binary complexes. Maced. J. Chem. Chem. Eng. 27(2), 157-162 (2008)

21. Bottei, R.S., Schneggenburger, R.G.: Thermogravimetric study of some divalent transition metal chelates of several amino acids. J. Therm. Anal. 2, 11-23 (1970) 
22. Shoukry, M.M.: Potentiometric studies of the complex formation between trimethyltin(IV) and some selected amino acids. J. Inorg. Biochem. 48, 271-277 (1992)

23. Ming, X.F., Rajapakse, A.G., Carvas, J.M., Ruffieux, J., Yang, Z.: Inhibition of S6K1 accounts partially for the anti-inflammatory effects of the arginase inhibitor L-norvaline. BMC Cardiovasc. Disords. 9(12) (2009). doi:10.1186/1471-2261-9-12

24. Sit, C.S., Vederas, J.C.: Approaches to the discovery of the new antibacterial agents based on bacteriocins. Biochem. Cell Biol. 86, 116-123 (2008)

25. Kisumi, M., Sugiura, M., Takagi, T., Chibata, I.: Norvaline accumulation by regulatory mutants of Serratia marcescens. J. Antibiot. 30, 111-117 (1977)

26. Soini, J., Falschlehner, C., Liedert, C., Bernhardt, J., Vuoristo, J., Neubauer, P.: Norvaline is accumulated after a down-shift of oxygen in Escherichia coli W3110. Microb. Cell Fact. 7(30) (2008). doi:10.1186/1475-2859-7-30

27. Tagashira, M., Nozato, N., Isonishi, S., Okamoto, A., Ochiai, K., Ohtake, Y.: 5-Hydroxy-4-oxo-Lnorvaline depletes intracellular glutathione: a new modulator of drug resistance. Biosci. Bitechnol. Biochem. 63, 1953-1958 (1999)

28. Jiang, J.D., Zhang, H., Li, J.N., Roboz, J., Qiao, W.B., Holland, J.F., Bekesi, G.: High anticancer efficacy of L-proline- $m$-bis(2-chloroethyl) amino-L-phenylalanyl-L-norvaline ethyl ester hydrochloride (MF13) in vivo. Anticancer Res. 21(3B), 1681-1689 (2001)

29. Cooney, D.A., Jayaram, H.N., Milman, H.A., Homan, E.R., Pittillo, R., Geran, R.I., Ryan, J., Rosenbluth, R.J.: DON, CONV and DONV-III. Pharmacologic and toxicologic studies. Biochem. Pharmacol. 25, 1859-1870 (1976)

30. Robbins, R.J.: Phenolic acids in foods: an overview of analytical methodology. J. Agric. Food Chem. 51, 2866-2887 (2003)

31. Srinivasan, M., Sudheer, A.R., Menon, V.P.: Ferulic acid: therapeutic potential through its antioxidant property. J. Clin. Biochem. Nutr. 40, 92-100 (2006)

32. Simonyan, A.V.: Activity of cinnamic acid derivatives and new methods for their synthesis (review). Pharm. Chem. J. 27, 92-100 (1993)

33. Gans, P., Sabatini, A., Vacca, A.: Investigation of equilibria in solution. Determination of equilibrium constants with the HYPERQUAD suite of programs. Talanta 43, 1739-1753 (1996)

34. Alderighi, L., Gans, P., Ienco, A., Peters, D., Sabatini, A., Vacca, A.: Hyperquad simulation and speciation (HySS): a utility program for the investigation of equilibria involving soluble and partially soluble species. Coord. Chem. Rev. 184, 311-318 (1999)

35. Casolaro, M., Anselmi, C., Picciocchi, G.: The protonation thermodynamics of ferulic acid $/ \gamma$-cyclodextrin inclusion compounds. Thermochim. Acta 425, 143-147 (2005)

36. Ozkorucuklu, S.P., Beltran, J.L., Fonrodona, G., Barrón, D., Alsancak, G., Barbosa, J.: Determination of dissociation constants of some hydroxylated benzoic and cinnamic acids in water from mobility and spectroscopic data obtained by CE-DAD. J. Chem. Eng. Data 54, 807-811 (2009)

37. Kiss, T., Sovago, I., Gergely, A.: Critical survey of stability constants of complexes of glycine. Pure Appl. Chem. 63, 597-638 (1991)

38. Perrin, D.D.: Stability Constants of Metal Ions Complexes. Part B: Organic Ligands. Pergamon, Oxford (1979)

39. Khatoon, Z., Uddin, K.: Potentiometric investigations on the cadmium(II)-amino acid-imidazole systems (amino acid = glycine, DL-alanine or DL-valine). Polyhedron 9, 2437-2442 (1990)

40. Irving, H., Williams, R.J.P.: The stability of transition metal complexes. J. Chem. Soc., 3192-3210 (1953)

41. Nicholls, D.: Complexes and First-Row Transition Elements. Am. Elsevier, New York (1975)

42. Gispert, J.R.: Coordination Chemistry. Wiley-VCH, Weinheim (2008)

43. Basolo, F., Johnson, R.C.: Coordination Chemistry: The Chemistry of Metal Complexes, vol. 35. Benjamin, Menlo Park (1964) 